\title{
Bezpośredni skutek „dyrektywy obrończej” w polskim procesie karnym
}

\begin{abstract}
As of 27 November 2017 the deadline passed by which the European Union Directive 2013/48/EU on the right of access to a lawyer should have been implemented by the Member States in their respective legal systems. Poland completed the said responsibility only ostensibly, for no legal norms which regulate the standard of the right to formal defence contained in Polish Code of Criminal Procedure have been amended. This very situation makes it necessary to consider whether the norms of the directive in question may cause the so-called direct effect in Poland's domestic legal system, particularly: whether prosecuted individuals may directly invoke the directive in order to, based on its content, seek the assistance of a lawyer in the course of criminal proceedings. Therefore, it stands to reason that, at least in relation to some of the competences envisioned in the directive, such eventuality exists, whereas in remainder of the cases the judicial bodies are obliged to interpret the respective norms of the Code of Criminal Procedure in pro-EU manner, thereby elevating the standard of right to formal defence present in Polish criminal proceedings. Nonetheless, the real transposition of this directive should be postulated, since invoking its direct effect cannot exempt a Member State from implementing it in accordance with EU treaties as a way to harmonize domestic legal systems.
\end{abstract}

Keywords: EU law, direct effect, access to lawyer, Directive 2013/48/EU, criminal proceedings, right to defence, due process

\section{Dyrektywa $2013 / 48 /$ UE - historia powstania i (nie)implementacji}

Współpraca państw członkowskich Unii Europejskiej w zakresie prawa i procesu karnego, policji oraz bezpieczeństwa wewnętrznego nabrała w ostatnich latach nowej dynamiki w związku z wejściem w życie traktatu lizbońskiego ${ }^{1}$. Obecne regulacje - w przeciwieństwie do epoki „przedliz-

${ }^{1}$ M. Rogacka-Rzewnicka: Wptyw prawodawstwa unijnego na pozycję procesowa oskarżonego. W: Prawne problemy i wyzwania Unii Europejskiej. Red. Ł. PIsArczYK. Warszawa 2018, s. 243. 
bońskiej" - przyznają organom UE prawo stanowienia wiążących aktów ustawodawczych w tej sferze, nazywanej w nomenklaturze traktatowej „przestrzenią wolności, bezpieczeństwa i sprawiedliwości”. Jest ona jedną z tzw. kompetencji dzielonych UE (art. 4 ust. 2 lit. j Traktatu o funkcjonowaniu Unii Europejskiej), wykonywaną wspólnie przez UE i państwa członkowskie (w zakresie, w jakim UE swojej kompetencji nie wykonała art. 2 ust. 2 TFUE). Choć fundamentem tego obszaru integracji jest przede wszystkim wzajemne uznawanie i wykonalność wyroków sądowych w poszczególnych państwach członkowskich, art. 82 ust. 2 TFUE stanowi, iż „, $[\mathrm{w}]$ zakresie niezbędnym dla ułatwienia wzajemnego uznawania wyroków i orzeczeń sądowych, jak również współpracy policyjnej i wymiarów sprawiedliwości w sprawach karnych o wymiarze transgranicznym, Parlament Europejski i Rada, stanowiąc w drodze dyrektyw zgodnie ze zwykłą procedurą ustawodawczą, mogą ustanawiać normy minimalne [...] Dotyczą one: [...] b) praw jednostek w postępowaniu karnym [...]" oraz szeregu innych zagadnień. UE zyskała w ten sposób istotny instrument wpływu na prawodawstwo państw członkowskich w sferze wymiaru sprawiedliwości w sprawach karnych, z którego zresztą w ostatnich latach coraz częściej korzysta. Jednym z najważniejszych, z perspektywy praktyki wymiaru sprawiedliwości, przejawów działań prawodawczych UE na tym polu jest dyrektywa Parlamentu Europejskiego i Rady 2013/48/UE z dnia 22 października 2013 r. w sprawie prawa dostępu do adwokata w postępowaniu karnym i w postępowaniu dotyczącym europejskiego nakazu aresztowania oraz $\mathrm{w}$ sprawie prawa do poinformowania osoby trzeciej o pozbawieniu wolności i prawa do porozumiewania się z osobami trzecimi i organami konsularnymi w czasie pozbawienia wolności ${ }^{2}$ [dalej jako: „dyrektywa 2013/48/UE” lub „dyrektywa obrończa”3].

2 Dz.Urz.UE L 294/1 z dnia 6 listopada 2013 r.; inne istotne akty prawne UE na polu postępowania karnego to między innymi: dyrektywa Parlamentu Europejskiego i Rady 2010/64/UE z dnia 20 października 2010 r. w sprawie prawa do tłumaczenia ustnego i tłumaczenia pisemnego w postępowaniu karnym (Dz.Urz.UE L 280/1 z dnia 26 października 2010 r.), dyrektywa Parlamentu Europejskiego i Rady 2011/99/UE z dnia 13 grudnia 2011 r. w sprawie europejskiego nakazu ochrony (Dz.Urz.UE L 338/2 z dnia 21 grudnia 2011 r.), dyrektywa Parlamentu Europejskiego i Rady 2012/13/UE z dnia 22 maja 2012 r. w sprawie prawa do informacji w postępowaniu karnym (Dz.Urz.UE L 142/1 z dnia 1 czerwca 2012 r.), dyrektywa Parlamentu Europejskiego i Rady 2012/29/UE z dnia 25 października 2012 r. ustanawiająca normy minimalne w zakresie praw, wsparcia i ochrony ofiar przestępstw oraz zastępująca decyzję ramową Rady 2001/220/WSiSW (Dz.Urz.UE L 315/57 z dnia 14 listopada 2013 r.) oraz dyrektywa Parlamentu Europejskiego i Rady nr 2014/41/UE z dnia 3 kwietnia 2014 r. w sprawie europejskiego nakazu dochodzeniowego w sprawach karnych (Dz.Urz.UE L 130/1 z dnia 1 maja 2014 r.).

${ }^{3}$ Dla porządku należy tu zasygnalizować kwestię terminologiczną: dyrektywa obrończa w polskiej wersji językowej stanowi o „dostępie do adwokata”; w wersji angielskiej użyto sformułowania access to lawyer, zaś we francuskiej - accès à un avocat; chodzi za- 
Pokrótce wypada przypomnieć historię powstania tego aktu prawnego ${ }^{4}$. Dnia 30 listopada 2009 r. Rada UE przyjęła w drodze rezolucji harmonogram działań mających na celu umocnienie praw procesowych osób podejrzanych lub oskarżonych $\mathrm{w}$ postępowaniu karnym ${ }^{5}$. Z harmonogramu tego wynikało, że jednym z priorytetowych działań jest przyjęcie środka oznaczonego literą C, o nazwie „porada prawna i pomoc prawna”. Te dwie kwestie w dalszych pracach zostały jednak rozdzielone - dyrektywa 2013/48/UE jest efektem prac nad zagadnieniem „porady prawnej”6. Znaczny wpływ na przyjęte rozwiązania miały standardy strasburskie, wynikające przede wszystkim z wyroku Europejskiego Trybunału Praw Człowieka w sprawie Salduz i kontynuowanej na jego podstawie linii orzeczniczej $^{7}$, kształtującej tzw. doktrynę Salduz w zakresie dostępu do adwokata we wczesnej fazie postępowania karnego ${ }^{8}$. W toku prac nad omawianym aktem ustawodawczym UE ujawnił się szereg rozbieżności i kontrowersji między państwami członkowskimi, Komisją Europejską oraz Parlamentem Europejskim ${ }^{9}$, aż po dwóch latach negocjacji dyrektywa obrończa została, w obecnym kształcie, przyjęta.

Zgodnie z art. 15 ust. 1 dyrektywy 2013/48/UE termin na jej transpozycję do krajowych porządków prawnych upływał dnia 27 listopada 2016 r., do czego jednak w Polsce nie doszło. W wystąpieniu z dnia 5 czerwca 2017 r. do Ministra Sprawiedliwości-Prokuratora Generalnego Rzecznik Praw Obywatelskich zwrócił się o podjęcie niezwłocznych prac nad implementacją dyrektywy obrończej, bowiem w jego ocenie - wbrew sta-

tem o dostęp do prawnika mogącego wykonywać funkcję obrońcy (co w Polsce oznacza również radcę prawnego). Z tego względu zaproponowano nazywanie przedmiotowej dyrektywy „dyrektywą obrończą”, a pojęcia „adwokat”, jako użyte w polskim tłumaczeniu dyrektywy, i „obrońca”, jako jego funkcjonalny odpowiednik w k.p.k., będą w tym tekście używane zamiennie.

${ }^{4}$ Obszerniej jego powstanie omawiają A. KlamczyńsKa, T. Ostropolski: Prawo do adwokata $w$ dyrektywie 2013/48/UE - tło europejskie i implikacje dla polskiego ustawodawcy. „Białostockie Studia Prawnicze” 2014, z. 15, s. 143-149.

${ }^{5}$ Rezolucja Rady z dnia 30 listopada 2009 r. dotycząca harmonogramu działań mających na celu umocnienie praw procesowych osób podejrzanych lub oskarżonych w postępowaniu karnym (tekst mający znaczenie dla EOG), Dz.Urz.UE C 295/1 z dnia 4 grudnia 2009 r.

${ }^{6}$ A. Klamczyńska, T. Ostropolski: Prawo do adwokata..., s. 146.

7 Wyrok ETPC z dnia 27 listopada 2008 r. w sprawie Salduz p. Turcji, skarga nr 36391/02; doktryna kontynuowana m.in. w wyroku ETPC z dnia 31 marca 2009 r. w sprawie Płonka p. Polsce, skarga nr 20310/02; istotą doktryny Salduz jest uznanie, że depozycje osoby ściganej, szczególnie samoobciążające, złożone bez zapewnienia jej dostępu do adwokata, nie podlegają dowodowemu wykorzystaniu, a ewentualne naruszenie tego zakazu co do zasady przekreśla rzetelność postępowania przeciwko tej osobie.

8 A. Klamczyńska, T. Ostropolski: Prawo do adwokata..., s. 146.

${ }^{9}$ Ibidem, s. 147-149. 
nowisku Ministerstwa Sprawiedliwości wyrażonemu w odpowiedzi na pierwsze pytanie Rzecznika ze stycznia 2017 r. - polski porządek prawny, a w szczególności przepisy k.p.k., nie zawierają gwarancji odpowiadających standardom wyrażonym $\mathrm{w}$ treści przedmiotowej dyrektywy ${ }^{10}$. Ministerstwo Sprawiedliwości nie odniosło się w żaden sposób do stanowiska RPO, dlatego Rzecznik w piśmie z dnia 4 lipca 2018 r. zwrócił się bezpośrednio do Prezesa Rady Ministrów o zainteresowanie się problemem. Rzecznik wskazał m.in., że rządowy projekt ustawy implementującej dyrektywę Parlamentu Europejskiego i Rady 2014/41/UE z dnia 3 kwietnia 2014 r. w sprawie europejskiego nakazu dochodzeniowego w sprawach karnych ${ }^{11}$ dodaje do tytułu k.p.k. odnośnik wskazujący, iż ustawa karnoprocesowa realizuje postanowienia dyrektywy obrończej ${ }^{12}$, mimo że w treści ustawy nowelizującej brak jest jakiegokolwiek przepisu zmieniającego regulacje k.p.k. odnoszące się do omawianej problematyki. W istocie ustawa z dnia 10 stycznia 2018 r. o zmianie ustawy - Kodeks postępowania karnego oraz niektórych innych ustaw ${ }^{13} \mathrm{~W}$ art. 1 pkt 1 dodała do tytułu k.p.k. odnośnik wskazujący na implementację przepisów dyrektywy 2013/48/UE, ale żaden odnośny przepis k.p.k. nie został przez tę nowelizację zmieniony.

Uprzedzając nieco dalsze rozważania, należy co do zasady zgodzić się z diagnozą wyrażoną przez RPO w przywołanych wyżej wystąpieniach, konstatując zarazem, że w ustawie karnoprocesowej zaistniała legislacyjna osobliwość - zawiera ona deklaratywne stwierdzenie o wykonywaniu aktu prawa unijnego, niepoparte jednak treścią przepisów tej ustawy. Niezależnie od tej obserwacji treść odnośnika do tytułu ustawy nie może być miarodajnym i wystarczającym czynnikiem dla rozstrzygnięcia, jaka jest normatywna zawartość k.p.k. - przedmiotem wykładni mogą być tylko te postanowienia ustawy, które są jej uporządkowanymi jednostkami redakcyjnymi, względnie tytułami jej części. Dyskusja nad przyczynami zaistniałego stanu rzeczy zdecydowanie wykracza poza ramy niniejszego opracowania - zgodzić się niewątpliwie trzeba z diagnozą, że to dość swobodne podejście do traktatowego obowiązku implementacji dyrektywy jest związane z materią dyrektywy obrończej, rozbudowującej prawa proceduralne jednostki. Tego rodzaju uprawnienia są zaś ciągle nierozumiane

${ }^{10}$ Wystąienie RPO do Ministra Sprawiedliwości-Prokuratora Generalnego z dnia 5 czerwca 2017 r., znak pisma II.51509.9.2014, s. 1-2.

11 Vide adres publikacyjny tej dyrektywy w przyp. 2.

12 Druk sejmowy nr 1931 Sejmu RP VIII kadencji; Wystąpienie RPO do Prezesa Rady Ministrów z dnia 4 lipca 2018 r., znak pisma II.5150.9.2014.MM, s. 6-7.

${ }^{13}$ Dz.U. poz. 201. 
i drugorzędnie traktowane w polskiej kulturze prawnej ${ }^{14}$. Równocześnie artykuł naukowy nie jest najlepszym miejscem na rozważanie przyczyny natury politycznej, stąd i w tym zakresie nie sposób odnieść się do powstałego zaniechania.

Upływ ponad dwóch lat od terminu transpozycji przedmiotowej dyrektywy skłania natomiast do pogłębienia refleksji nad obecnym stanem prawnym w zakresie normowanym dyrektywą obrończą. W pierwszej kolejności refleksja ta wymaga potwierdzenia postawionej wyżej tezy o rozbieżności między standardem wynikającym z dyrektywy 2013/48/UE a standardem przyjętym w k.p.k. $Z$ tego względu w punkcie 2 niniejszego opracowania przedstawione zostały wyrażane jeszcze w tzw. okresie przejściowym do implementacji dyrektywy opinie o znacznej rozbieżności między treścią przedmiotowej dyrektywy a przepisami k.p.k. i konieczności dostosowania tych ostatnich do prawa unijnego. Stan sprzeczności między prawem krajowym i unijnym nie może być jednak bez końca utrzymywany - wobec braku spodziewanych inicjatyw legislacyjnych w tej mierze zbadać należy, jakimi środkami zaradczymi dysponują organy stosujące prawo, aby tej sprzeczności przeciwdziałać. Punkt 3 zawiera omówienie w sposób ogólny jedno z remediów uzgadniających z prawem UE w konkretnych rozstrzygnięciach rezultaty stosowania prawa krajowego, a mianowicie możliwość przyjęcia skutku bezpośredniego dyrektywy. W punkcie 4 przeprowadzone zostały rozważania odnoszące się ściśle do dyrektywy obrończej i możliwości wywoływania przez nią bezpośredniego skutku w polskim procesie karnym, względnie perspektyw dokonywania prounijnej wykładni stosownych przepisów k.p.k. Punkt 5 zawiera podsumowanie przedstawionej problematyki, z uwzględnieniem faktu, że omawiana dyrektywa nie funkcjonuje w próżni legislacyjnej i pozostaje w związku z innymi aktami prawa unijnego, których stan implementacji do polskiego porządku prawnego również pozostawia wiele do życzenia, a działania legislacyjne w tej mierze są - niezależnie od ich merytorycznej treści - opóźnione.

\section{Treść dyrektywy obrończej i propozycje kierunku jej transpozycji do prawa polskiego}

Jak zaznaczono wyżej, podstawowym celem przestrzeni wolności, bezpieczeństwa i sprawiedliwości w UE jest umacnianie zasady wzajemnego uznawania orzeczeń. Z tego formalnego, zdawałoby się, zagadnienia wy-

14 T. Koncewicz, A. Podolska: Dostęp do adwokata w postępowaniu karnym. Pal. 2017, nr 9, s. 21-22. 
pływa jednak szereg konsekwencji oddziałujących na całokształt procedur prowadzących do powstania tych orzeczeń. Motyw 6 dyrektywy 2013/ 48/UE trafnie stanowi, że „[w]zajemne uznawanie orzeczeń w sprawach karnych może skutecznie funkcjonować jedynie w duchu zaufania, w którym nie tylko organy sądowe, ale wszyscy uczestnicy postępowania karnego traktują orzeczenia organów sądowych innych państw członkowskich jako równoważne swoim własnym, z czym wiąże się nie tylko zaufanie do adekwatności przepisów innych państw członkowskich, ale także zaufanie do tego, że przepisy te są prawidłowo stosowane. Zwiększenie wzajemnego zaufania wymaga szczegółowych przepisów dotyczących ochrony praw i gwarancji procesowych wynikających z Karty [Praw Podstawowych K.O.], EKPCz i MPPOP. Wymaga ono również dalszego rozwinięcia w ramach Unii - poprzez niniejszą dyrektywę oraz poprzez inne środki - norm minimalnych określonych w Karcie i w EKPCz". Ustanowione przez dyrektywę obrończą normy minimalne różnią się zaś - niekiedy w istotny sposób - od odpowiadających im regulacji k.p.k.

W pierwszej kolejności należy wskazać na zakres podmiotowy prawa do obrony formalnej w k.p.k., które zgodnie z art. 6 k.p.k. przysługuje „oskarżonemu" w sensie ogólnym, tj. podejrzanemu i oskarżonemu sensu stricto (art. $71 \S 3$ k.p.k.). Pozostając przy literalnym brzmieniu tych norm, $\mathrm{z}$ perspektywy temporalnej prawo do obrony formalnej powstaje $\mathrm{z}$ chwila przedstawienia zarzutów ( $\mathrm{w}$ formie postanowienia albo podania ich do protokołu w związku z czynnością przesłuchania). Biorą się stąd pewne wątpliwości, na ile prawo to można rozciągnąć na tzw. osobę podejrzaną, przede wszystkim $\mathrm{w}$ związku z problemami definicyjnymi otaczającymi to pojęcie ${ }^{15}$. Istnieją dość stabilne podstawy do konstruowania tego prawa wobec osoby zatrzymanej, a to ze względu na treść art. $245 \S 1$ k.p.k. pogląd taki wyrażał zresztą Trybunał Konstytucyjny i Sąd Najwyższy ${ }^{16}$. Tymczasem dyrektywa obrończa znacznie precyzyjniej rozstrzyga tę kwestię - art. 2 ust. 1 tego aktu stanowi, że „[n]iniejszą dyrektywę stosuje się do podejrzanych lub oskarżonych w postępowaniu karnym od chwili poinformowania ich przez właściwe organy państwa członkowskiego, za pomocą oficjalnego powiadomienia lub w inny sposób, o tym, że są podejrzani lub oskarżeni o popełnienie przestępstwa, niezależnie od tego, czy zostali pozbawieni wolności”. Nie ulega zatem wątpliwości, że prawo do obrony formalnej rozciąga się, w świetle dyrektywy obrończej, na osoby podejrzane, przeciwko którym podjęto jakąkolwiek czynność procesową związaną z poinformowaniem ich o zarzucie, a nawet wezwano je do sta-

15 R. Koper: Prawo do obrony osoby podejrzanej. PiP 2016, nr 2, s. 18-21.

16 Vide wyrok TK z dnia 11 grudnia 2012 r., K 37/11, OTK ZU 11A/2012, poz. 133 i cytowane w punkcie 2.3 tego wyroku orzecznictwo SN. 
wiennictwa w charakterze podejrzanego w celu przedstawienia zarzutów i przesłuchania, co potwierdza art. 3 ust. 1 lit. a przedmiotowej dyrektywy. Niezależnie od jedynie sygnalizowanych wyżej kontrowersji de lege lata co do zakresu podmiotowego prawa od obrony formalnej w k.p.k. dyrektywa 2013/48/UE jest instrumentem, który - gdyby został prawidłowo wdrożony - wątpliwości te by w znacznym zakresie usunął.

Następnym zagadnieniem jest treść prawa do obrony formalnej. Dyrektywa obrończa przewiduje, że składają się nań trzy podstawowe uprawnienia: (1) prawo do spotkania się i porozumiewania z obrońcą, jeszcze przed przesłuchaniem; (2) prawo do obecności i aktywnego udziału obrońcy w przesłuchaniu podejrzanego lub oskarżonego oraz (3) prawo do obecności obrońcy podczas czynności dowodowych niepowtarzalnych (okazanie, konfrontacja, eksperyment procesowy). Konfrontując treść pierwszego z uprawnień z regulacjami k.p.k., dojść należy do wniosku, że jest to prawo przewidziane w polskiej procedurze karnej (art. 73 $\S 1$ k.p.k., art. $245 \S 1$ k.p.k.). Warto zarazem zauważyć, że przepisy k.p.k. gwarantują to prawo tylko w odniesieniu do osób faktycznie pozbawionych wolności - poza zainteresowaniem ustawodawcy, co oczywiste i godne aprobaty, pozostają kontakty z obrońcą podejmowane przez podejrzanego lub oskarżonego pozostającego na wolności. W takich warunkach jest to bowiem sfera całkowicie swobodnego postępowania tych podmiotów, chroniona tajemnicą obrończą. Kontakt z obrońcą osoby pozbawionej wolności jest natomiast szczególnym wyjątkiem od sytuacji, w której osoba taka traci de facto również swobodę komunikowania się $\mathrm{z}$ innymi osobami według swojego wyboru.

Bardziej problematyczne na gruncie prawa polskiego jest drugie $\mathrm{z}$ omawianych wyżej praw, albowiem z art. 301 k.p.k., odnoszącego się do pierwszego przesłuchania podejrzanego (czynności o nadzwyczajnej wadze w postępowaniu karnym), wynika, jak przyjmuje doktryna, pięć następujących reguł związanych z udziałem w nim obrońcy: „(1) organ procesowy ma obowiązek umożliwić wzięcie udziału przez obrońcę w przesłuchaniu, a więc zawiadomić o tym przesłuchaniu tylko wówczas, gdy podejrzany ma już ustanowionego obrońcę; (2) organ procesowy nie ma obowiązku odroczenia przesłuchania w celu umożliwienia podejrzanemu ustanowienia obrońcy i zawiadomienia go o terminie przesłuchania; (3) w razie, gdy podejrzany nie zostanie przesłuchany z udziałem obrońcy, może on po ustanowieniu lub wyznaczeniu obrońcy ponowić żądanie przesłuchania go z udziałem obrońcy, ponieważ przepis art. 301 k.p.k. nie ogranicza tego prawa do pierwszego przesłuchania; w razie zgłoszenia takiego żądania organ procesowy musi je uwzględnić; (4) prawo do żądania przesłuchania z udziałem obrońcy wyczerpuje się po jednokrotnym przesłuchaniu z udziałem obrońcy; (5) niestawiennictwo obrońcy, także usprawiedliwio- 
ne, nie tamuje przesłuchania" ${ }^{17}$. Trafnie wskazuje S. Steinborn, że te implikacje art. 301 k.p.k. pozostają w sprzeczności z niemal bezwarunkowym charakterem omawianego uprawnienia na gruncie dyrektywy obrończej stan prawny implementujący dyrektywę powinien prawo do przesłuchania z udziałem obrońcy skonstruować podobnie i nie uznawać go za uprawnienie jednokrotne, a każdoczesne, gdy tylko dochodzi do przesłuchania podejrzanego lub oskarżonego. Nadto przepis zgodny z przedmiotową dyrektywą winien nakazywać organom procesowym wstrzymanie się z przeprowadzeniem tej czynności ${ }^{18}$, jeżeli podejrzany obrońcy nie ma, a chce go ustanowić, oraz umożliwienie mu kontaktu z obrońcą przed przesłuchaniem. Przepis taki powinien również przewidywać, że usprawiedliwione niestawiennictwo obrońcy tamuje czynność przesłuchania podejrzanego ${ }^{19}$.

Należy również wyrazić wątpliwość, czy w zakresie trzeciego z uprawnień k.p.k. spełnia omawiany tu standard unijny ${ }^{20}$. Odnoszący się do udziału w czynnościach niepowtarzalnych art. $316 \S 1$ k.p.k. nakazuje dopuścić obrońcę do udziału w takich czynnościach, jeżeli jest już ustanowiony $\mathrm{w}$ sprawie i nie zachodzi niebezpieczeństwo utraty lub zniekształcenia dowodu w razie zwłoki. O ile drugie ograniczenie odnosi się do wyjątków przewidzianych w dyrektywie obrończej, o których dalej, o tyle pierwsze nie może być utrzymane. Należy konsekwentnie stwierdzić, że skoro z przedmiotowej dyrektywy wywodzi się - na gruncie prawa do obecności przy przesłuchaniu - obowiązek jego odłożenia w czasie w celu ustanowienia obrońcy przez podejrzanego lub oskarżonego, to tym bardziej obowiązek ten powinien dotyczyć udziału w czynności niepowtarzalnej ${ }^{21}$. Uzasadnia ten argument brzmienie art. 117 § 2 k.p.k., dość wąsko ujmującego przesłanki nieprzeprowadzenia czynności w razie niestawiennictwa osoby uprawnionej (co do zasady jest to możliwe). Nieustanowiony obrońca siłą rzeczy taką „osobą uprawnioną” nie jest, dlatego trudno na podstawie tej normy ogólnej wywodzić obowiązek odroczenia czynności dowodowej niepowtarzalnej w celu ustanowienia przez stronę bierną procesu obrońcy. Czynność niepowtarzalna nie może

17 Opinia Komisji Kodyfikacyjnej Prawa Karnego w sprawie implementacji w prawie polskim dyrektywy Parlamentu Europejskiego i Rady 2013/48/UE z dnia 22 października 2013 r. $w$ sprawie prawa dostępu do adwokata $w$ postępowaniu karnym $i$ w postępowaniu dotyczacym europejskiego nakazu aresztowania oraz $w$ sprawie prawa do poinformowania osoby trzeciej o pozbawieniu wolności i prawa do porozumiewania się z osobami trzecimi i organami konsularnymi $w$ czasie pozbawienia wolności. Oprac. S. STEINBORN, s. 3 i podawana tam dalsza literatura.

18 A. KlamczyńsKa, T. Ostropolski: Prawo do adwokata..., s. 157.

19 Opinia Komisji Kodyfikacyjnej Prawa Karnego..., s. 4.

20 Odmiennie - ibidem, s. 5.

${ }^{21}$ Podobnie - A. Klamczyńska, T. Ostropolski: Prawo do adwokata..., s. 157. 
zaś ze swojej natury podlegać najbardziej efektywnej kontroli na rozprawie głównej, jaką byłoby jej ponowne przeprowadzenie, co mogłoby zarazem służyć konwalidacji jej ewentualnych braków. Sąd orzekający zdany jest w zasadzie wyłącznie na treść właściwie ujawnionego protokołu takiej czynności z postępowania przygotowawczego, co stanowi daleko idący i co do zasady niepożądany przecież wyjątek od zasady bezpośredniości. Z tych względów przeprowadzanie każdej czynności niepowtarzalnej powinno być zawsze obudowane daleko idącymi gwarancjami procesowymi dla stron.

Osobną kwestią są ujęte w dyrektywie 2013/48/UE wyjątki od przewidzianych w niej i omówionych wyżej uprawnień. Art. 3 ust. 6 przedmiotowej dyrektywy stanowi, że „,w] wyjątkowych okolicznościach i jedynie na etapie postępowania przygotowawczego państwa członkowskie moga zastosować czasowe odstępstwo od stosowania praw przewidzianych w ust. 3, w zakresie, w jakim jest to uzasadnione - w świetle konkretnych okoliczności danej sprawy - jednym z następujących istotnych powodów: a) w przypadku pilnej potrzeby zapobieżenia poważnym negatywnym konsekwencjom dla życia, wolności lub nietykalności cielesnej jakiejś osoby; b) w przypadku konieczności podjęcia przez organy ścigania natychmiastowego działania w celu niedopuszczenia do narażenia postępowania karnego na znaczący uszczerbek”. W odniesieniu do pierwszego z uprawnień, tj. prawa od poufnych kontaktów z obrońcą, polski porządek prawny przewiduje tego rodzaju ograniczenia w art. 73 § 2 i 3 k.p.k. - jako przesłanki tych ograniczeń przepis ten wskazuje dobro postępowania przygotowawczego i zaistnienie szczególnie uzasadnionego wypadku; granice czasowe tych ograniczeń to 14 dni od dnia tymczasowego aresztowania podejrzanego (czyli od dnia zatrzymania poprzedzającego stosowanie tego środka zapobiegawczego - art. 265 k.p.k.). Przepisy transponujące dyrektywę powinny w szczególności uwzględnić przesłankę wyrażoną pod lit. a w przywołanym wyżej przepisie dyrektywy obrończej - w pozostałym zakresie wydają się z nią zgodne ${ }^{22}$. W zakresie drugiego z uprawnień, tj. prawa do udziału obrońcy w przesłuchaniu, obydwa omawiane wyjątki muszą być w całości implementowane, jak i treść samego uprawnienia musi być dostosowana do przedmiotowej dyrektywy. Przepisy po transpozycji mogłyby przewidywać m.in. maksymalny czas, na jaki istniałaby możliwość odroczenia przesłuchania w celu ustanowie-

22 Stanowisko, iż poufność kontaktów z obrońcą ma jednak charakter niemal absolutny, a obecna regulacja wymaga fundamentalnej zmiany, zdają się wyrażać Uwagi Sądu Najwyższego do projektu ustawy o zmianie ustawy - Kodeks postępowania karnego oraz niektórych innych ustaw z dnia 12 marca 2019 r., s. 4 (dot. druku sejmowego nr 3251 Sejmu RP VIII kadencji). 
nia lub zapewnienia stawiennictwa obrońcy ${ }^{23}$. Sytuacja przedstawia się podobnie $\mathrm{w}$ odniesieniu do trzeciego z uprawnień, czyli udziału obrońcy w czynnościach niepowtarzalnych.

Wyjątki z art. 3 ust. 6 dyrektywy 2013/48/UE podlegają dodatkowo art. 8 ust. 1 tejże dyrektywy, zgodnie z którym czasowe ograniczenia uprawnień ustalonych $\mathrm{w}$ dyrektywie muszą być proporcjonalne, ściśle ograniczone w czasie, nie mogą opierać się wyłącznie na wadze lub rodzaju zarzuconego przestępstwa i nie mogą naruszać ogólnej rzetelności postępowania. Powstaje pytanie, na ile te zasady stosowania omawianych ograniczeń nadają się do transponowania. Niewątpliwie drugi i trzeci z wskazanych tu warunków mają taki charakter - dla przepisów k.p.k. oznacza to w praktyce utrzymanie terminu ustalonego w art. $73 \S 4$ k.p.k. i wprowadzenie (ewentualnie) analogicznych terminów dla ograniczeń pozostałych uprawnień, a także niewprowadzanie do treści k.p.k. jakiegokolwiek katalogu czynów, w wypadku których stosowanie tych ograniczeń byłoby per se usprawiedliwione. Warunek proporcjonalności i zachowania ogólnej rzetelności postępowania należy raczej uznać za postulat kierowany do organów procesowych i ich działalności, a pod kątem ściśle normatywnym - za sugestię przesłanek, według których powinna dodatkowo podlegać sądowa kontrola tych ograniczeń. Zauważyć bowiem trzeba, że zgodnie z art. 8 ust. 2 dyrektywy obrończej „[n]a czasowe odstępstwa na mocy art. 3 ust. 5 lub 6 można zezwolić jedynie w drodze należycie uzasadnionej decyzji podjętej w trybie indywidualnym przez organ sądowy lub przez inny właściwy organ, pod warunkiem, że decyzja ta może podlegać kontroli sądowej". Prawidłowa transpozycja tej regulacji do k.p.k. oznaczałaby, że decyzje prokuratora w omawianym przedmiocie powinny podlegać kontroli zażaleniowej, albowiem ustrojowe usytuowanie prokuratury w Polsce w obecnym modelu wyklucza uznawanie jej za „organ sądowy” w rozumieniu przepisów dyrektywy 2013/48/UE²4. Poza ogólnymi warunkami dopuszczalności tych ograniczeń proporcjonalność i rzetelność postępowania w całości powinny stanowić dodatkowe przesłanki tej kontroli.

Słuszny jest także postulat, aby uznanie tego ograniczenia za niedopuszczalne skutkowało niemożnością procesowego wykorzystania uzyskanych bez obecności obrońcy wyjaśnień ${ }^{25}$. Należy zarazem zaznaczyć, że tego rodzaju sankcja, wykluczająca moc dowodową wyjaśnień złożonych

\footnotetext{
${ }^{23}$ Konkretne propozycje zawarto w Opinii Komisji Kodyfikacyjnej Prawa Karnego..., s. 4.

${ }^{24}$ Podobnie - ibidem, s. 4-5, 11; S. STEInborn: Dostęp do obrońcy na wczesnym etapie postępowania karnego. Uwagi de lege lata $i$ de lege ferenda. EPS 2019, nr 1, s. $44-45$.

${ }^{25}$ Opinia Komisji Kodyfikacyjnej Prawa Karnego..., s. 5.
} 
bez obrońcy, nie jest w samej dyrektywie obrończej wprost przewidziana. Projekt dyrektywy zakładał, co prawda, wprowadzenie takiej sankcji w sposób wyraźny, ale opór państw członkowskich doprowadził do złagodzenia jej ostatecznego brzmienia (art. 12 ust. 2 dyrektywy obrończej przewiduje jedynie obowiązek zapewnienia przez państwa członkowskie, by „w postępowaniu karnym przy ocenie wyjaśnień złożonych przez podejrzanych lub oskarżonych lub dowodów uzyskanych z naruszeniem ich prawa dostępu do adwokata lub w przypadkach, gdy zezwolono na odstępstwo od tego prawa zgodnie $\mathrm{z}$ art. 3 ust. 6, przestrzegane były prawo do obrony i prawo do rzetelnego postępowania"). Wyraża się w związku z tym pogląd, że ustanowienie przedmiotowej sankcji jest możliwym sposobem wdrożenia dyrektywy, ale nie jest sposobem jedynym ${ }^{26}$. Nie sposób jednak nie zauważyć, że dyrektywa, realizując przepisy Karty Praw Podstawowych, musi być z nią zgodna, a art. 52 ust. 3 tejże Karty wyraźnie stwierdza, że unijnymi standardami minimalnymi (mogącymi ulec podwyższeniu) są standardy wynikające z Konwencji o Ochronie Praw Człowieka i Podstawowych Wolności oraz orzecznictwa ETPC. W przedmiotowym zakresie zastosowanie zaś ma wspomniana już doktryna Salduz, a dyrektywę obrończą uważa się za przeniesienie na grunt prawa unijnego tej doktryny ${ }^{27}$. Propozycja omawianej sankcji w sferze dopuszczalności dowodów niewątpliwie pozostaje w „duchu” dyrektywy, choć nie wynika wprost z jej litery ${ }^{28}$. Konsekwentnie przyjęcie takiej sankcji wobec wyjaśnień uzyskanych bez obrońcy powinno również oznaczać zakaz wykorzystania danych zebranych w toku czynności niepowtarzalnej, przeprowadzonej bez jego udziału.

Jak widać z powyższej analizy, k.p.k. pozostaje w wielu badanych punktach rozbieżny z wymogami dyrektywy 2013/48/UE. Nie wyczerpuje to $\mathrm{w}$ żaden sposób problematyki niezbędnych kroków legislacyjnych uzgadniających treść k.p.k. z prawem unijnym w tym zakresie: implementacja dyrektywy obrończej rodziłaby również dodatkowe problemy co do transpozycji prawa do zrzeczenia się uprawnień (art. 9 przedmiotowej

${ }^{26}$ M. WĄSEK-WIADEREK: Dostęp do adwokata na wczesnym etapie postępowania karnego $w$ prawie Unii Europejskiej. EPS 2019, nr 1, s. 21-22.

${ }^{27}$ Ibidem, s. 20.

${ }_{28}$ Problem jest niezwykle złożony i zahacza o zagadnienia relacji ustrojowych między Unią a państwami członkowskimi; jakkolwiek ostatnie zdanie motywu 50 dyrektywy obrończej gwarantuje państwom swobodę w sferze utrzymania dotychczasowego systemu postępowania dowodowego na rozprawie, to trudno jednocześnie przyjąć takie rozumienie skutków dyrektywy w prawie krajowym, które obniżałoby standard strasburski określony w orzeczeniu Salduz; jednocześnie orzecznictwo ETPC w tej mierze przechodzi, jak trafnie zauważa M. Wąsek-Wiaderek (Dostęp do adwokata..., s. 22), istotną ewolucję po wyroku w sprawie Ibrahim (połączone skargi nr 50541/08, 50571/08, 50573/08, 40351/09), co może, niestety, poddawać w wątpliwość aktualność doktryny Salduz w przyszłości. 
dyrektywy), a także regulacji odnoszących się do procedury europejskiego nakazu aresztowania (art. 10 przedmiotowej dyrektywy). Ograniczyć się trzeba jednak, ze względu na ramy opracowania, do przepisów omówionych wyżej, stanowiących niewątpliwie „rdzeń” tej dyrektywy z perspektywy posunięć prawodawczych i praktyki organów procesowych. Ze względów, o których dalej, należy uznać te regulacje za mające największy potencjał na wywoływanie w prawie krajowym skutku bezpośredniego. Wobec zaistniałego stanu niezgodności prawa krajowego z prawem UE rozważenie możliwości skutku bezpośredniego dyrektywy obrończej jawi się jako pragmatyczna potrzeba. Szczegółowe rozważania w tej mierze należy jednak poprzedzić szkicem ogólnej problematyki skutku bezpośredniego prawa unijnego.

\section{Możliwość przyjęcia bezpośredniego skutku dyrektywy unijnej w krajowym porządku prawnym}

W stanowiącym „kamień milowy” prawa unijnego (wcześniej: wspólnotowego) orzeczeniu Trybunału Sprawiedliwości UE [dalej jako: TSUE] w sprawie van Gend en $\operatorname{Loos}^{29}$ stwierdzono, że „Wspólnota stanowi nowy porządek prawny w prawie międzynarodowym, na rzecz którego państwa ograniczyły, jakkolwiek tylko w wąskich dziedzinach, swoje prawa suwerenne, i którego normy znajdują zastosowanie nie tylko do państw członkowskich, ale i pochodzących z nich jednostek [...] w związku z tym prawo wspólnotowe, niezależne od ustawodawstwa państw członkowskich, nie tylko nakłada na jednostki zobowiązania, lecz może również być źródłem uprawnień stanowiących element statusu prawnego tych jednostek [...] nie muszą to być uprawnienia nadane wprost w traktacie, lecz że powstają one również jako skutek zobowiązań, które traktat nakłada w sposób ściśle określony zarówno na jednostki, jak i na państwa członkowskie oraz instytucje wspólnotowe”. Wyrok ten dał początek tzw. zasadzie skutku bezpośredniego, związanej ze stosowaniem prawa unijnego $\mathrm{w}$ porządku prawnym państw członkowskich. W cytowanym wyroku po raz pierwszy użyto określenia „bezpośrednio skuteczny” w odniesieniu do przepisu prawa stanowionego przez ówczesną Europejską Wspólnotę Gospodarczą, której swoistym „sukcesorem” jest UE. Zauważyć trzeba zarazem, że zasada bezpośredniego skutku jest, w swoim tradycyjnym ujęciu, silnie spleciona z zasadą pierwszeństwa ${ }^{30}$ - sensem tej drugiej zasa-

${ }^{29}$ Wyrok TSUE z dnia 5 lutego 1963 r. w sprawie 26/62 NV Algemene Transport - en Expeditie Onderneming van Gend \& Loos.

${ }^{30}$ P. BRZEZIŃsKI: Unijny obowiazek odmowy zastosowania przez sad krajowy ustawy niezgodnej z dyrektywa Unii Europejskiej. Warszawa 2010, s. 33. 
dy jest przyznanie prawu unijnemu prymatu w razie konfliktu jego treści z prawem wewnętrznym, co rodzi obowiązek niestosowania prawa unijnego i rozstrzygania w oparciu o prawo unijne ${ }^{31}$.

Treścią zasady bezpośredniego skutku jest zatem możliwość stosowania przez sąd państwa członkowskiego UE prawa unijnego wprost, bez pośrednictwa normy prawa krajowego. Jest to istotna różnica w stosunku do klasycznego, najbardziej rozpowszechnionego, dualistycznego ujęcia skuteczności prawa międzynarodowego w prawie państwowym ${ }^{32}$. Ujęcie to zakłada, że skoro podmiotami prawa międzynarodowego są państwa, to żadna jednostka podległa ich władzy nie może opierać swoich roszczeń o traktaty, których stroną jest państwo, ani o międzynarodowe prawo zwyczajowe wiążące dany kraj. Normy te wymagają każdorazowo inkorporacji do prawa krajowego, czyli ich „przełożenia na język” odpowiedniego aktu prawa wewnętrznego, bowiem dopiero taki akt jest adresowany do jednostki podległej jurysdykcji państwa. Takiego wymogu nie stawia się jednak w ogóle niektórym aktom prawa unijnego - art. 288 TFUE przewiduje, w odniesieniu do rozporządzenia, że jest ono „bezpośrednio stosowane" w państwach członkowskich UE. Oznacza to, że państwa członkowskie nie muszą wydawać (co do zasady) żadnych przepisów wykonujących rozporządzenie w krajowym porządku prawnym. Inaczej jest w stosunku do dyrektyw, które zazwyczaj wymagają aktywności prawodawczej państwa, a traktaty nie zawierały i nie zawierają podobnego zastrzeżenia o bezpośredniej skuteczności.

Nie oznacza to jednak, że dyrektywa nie może wywoływać skutku bezpośredniego. W wyrokach w sprawie Ratti ${ }^{33}$ oraz w sprawie Becker ${ }^{34}$ postawiono tezę, która w drugim orzeczeniu przybrała następującą postać: „[b]yłoby [...] niezgodne z wiążącym charakterem, jaki mają dyrektywy [...], aby jednostki pozbawione były możliwości powoływania się na obowiązki ustanowione w dyrektywie. Zwłaszcza w przypadku, gdyby władze wspólnotowe nałożyły dyrektywą na państwa członkowskie obowiązek podjęcia określonych działań, skuteczność (effet utile) takiego aktu zostałaby osłabiona, gdyby zainteresowane podmioty nie mogły powołać się na ten akt przed sądem, a sądy krajowe nie mogły uwzględnić go jako elementu prawa wspólnotowego". W ten sposób dopuszczono, by również dyrektywa wywoływała skutek bezpośredni w prawie krajowym.

31 A. ŁazowsKi. W: Prawo instytucjonalne Unii Europejskiej. Red. M.M. KeNIG-WitkowsKa. Warszawa 2015, s. 294; P. BRzezIŃsKi: Unijny obowiązek..., s. 43.

32 W. GóralczyK, S. SAWICKI: Prawo międzynarodowe publiczne $w$ zarysie. Warszawa 2011, s. 30-38.

33 Wyrok TSUE z dnia 5 kwietnia 1979 r. w sprawie 148/78 Tullio Ratti.

34 Wyrok TSUE z dnia 19 stycznia 1982 r. w sprawie 8/81 Ursula Becker. 
TSUE od wielu lat kontynuuje tę linię orzeczniczą ${ }^{35}$, niemniej powoływanie się bezpośrednio na dyrektywę wymaga, zgodnie z tym orzecznictwem, spełnienia kilku warunków. Sytuacja jest stosunkowo prosta, gdy dyrektywa jest implementowana do prawa krajowego; komplikuje się natomiast w wypadku braku implementacji - i ten wypadek, ze względu na przedmiot niniejszego opracowania, należy tu szerzej omówić.

Brak implementacji oznacza, że w krajowym porządku prawnym nie zaistniały przepisy wykonujące konkretną dyrektywę (brak transpozycji). Jednocześnie jest ona dla państwa wiążąca, stąd brak implementacji stanowi naruszenie obowiązków traktatowych. W cytowanej wyżej sprawie Becker TSUE wyprowadził z takiego stanu rzeczy następującą konsekwencję: „państwo członkowskie, które nie wydało w wyznaczonym terminie przepisów wykonawczych wymaganych przez dyrektywę, nie może przeciwstawiać jednostkom niewykonania przez samo to państwo obowiązków ciążących na nim na mocy dyrektywy. W ten sposób, jeśli przepisy dyrektywy z punktu widzenia ich treści wydają się bezwarunkowe i wystarczająco precyzyjne, to wobec braku w wyznaczonych terminach przepisów wykonawczych można się na nie powołać wobec wszelkich przepisów prawa krajowego niezgodnych z dyrektywą bądź też, jeśli ich charakter pozwala określić uprawnienia, jakich jednostki mogą dochodzić od państwa”. Jest to przejaw doktryny estoppelu ${ }^{36}$, niekiedy wiązanej $\mathrm{z}$,zasadą czystych rąk" i paremią nemo auditur propriam turpitudinem allegans. $\mathrm{Z}$ wyrażonego tu stanowiska TSUE wynika, że państwo członkowskie nie może usprawiedliwiać określonego postępowania względem jednostki faktem niewykonania ciążących na nim prawnych, traktatowych obowiązków. W konsekwencji brak implementacji nie pozbawia jednostki ochrony wynikającej z przepisów dyrektywy unijnej - musi ona jednak posiadać kształt prawny umożliwiający przyznanie jej skutku bezpośredniego przez odpowiedni organ stosujący prawo.

Wyłania się na tym tle kontrowersja dotycząca dwóch znaczeń skutku bezpośredniego, przyjmowanych $\mathrm{w}$ doktrynie prawa unijnego, a mianowicie znaczenia subiektywnego i znaczenia obiektywnego. O pierwszym z nich doktryna wypowiada się następująco: „może się zdarzyć, że te same prawa przyznaje zarówno dyrektywa, jak i prawo krajowe, z tym że dyrektywa czyni to $\mathrm{w}$ szerszym zakresie. $\mathrm{W}$ takim wypadku jednostka ma prawo powołać się na przepisy dyrektywy, jeżeli jej przepisy, sformułowane w sposób jasny i precyzyjny, pozwalają na odkodowanie treści danego uprawnienia przysługującego określonej jednostce (bezpośredni skutek

35 Wyrok TSUE z dnia 5 października 2004 r. w sprawach połączonych od C-397/01 do C-403/01 Bernhard Pfeiffer i inni oraz powołane w punkcie 103 tego wyroku orzecznictwo.

36 P. BRzezIŃski: Unijny obowiązek..., s. 108-109. 
w znaczeniu subiektywnym). Sąd krajowy lub inny organ będący emanacją państwa nie może odmówić realizacji przysługujących jednostce praw"37. Dyrektywa ma zatem przyznawać jednostce prawo podmiotowe $^{38}$, aby można było mówić o skutku bezpośrednim w znaczeniu subiektywnym. W znaczeniu obiektywnym natomiast dyrektywa nie musi przyznawać jednostce prawa podmiotowego, ale wystarczy, by nakładała na państwa określone obowiązki, których wykonania jednostka może żądać ${ }^{39}$. Przykładem takiego rozumienia skutku bezpośredniego jest w orzecznictwie TSUE sprawa CIA Security ${ }^{40}$; z orzeczenia zapadłego w tej sprawie wynika, że jeżeli dyrektywa nałożyła na państwu określone obowiązki związane z notyfikacją tzw. przepisów technicznych, to brak tej notyfikacji pozwala jednostce żądać ich niestosowania, z powołaniem na przepisy dyrektywy zobowiązujące państwo członkowskie do notyfikacji. Z powyższego wynika, że skutek bezpośredni dyrektywy można przyjąć zarówno wówczas, gdy adresatem normy w niej zawartej jest jednostka, jak i wówczas, gdy adresatem jest państwo członkowskie, ale wykonanie tej normy ma znaczenie dla sytuacji prawnej jednostki. Niezależnie od powyższego wymaga się, aby przepisy dyrektywy były - w swej językowej redakcji - jasne, precyzyjne i bezwarunkowe ${ }^{41}$. Zauważono zarazem (sprawa van $D u y n^{42}$ ), że nawet jeśli istnieją wątpliwości co do właściwej i jednoznacznej wykładni takiego przepisu, to sąd krajowy dysponuje prawem (a czasem wręcz obowiązkiem) zadania TSUE pytania prejudycjalnego co do interpretacji takiego przepisu, skutkiem czego może być uznanie jego bezpośredniej skuteczności w prawie krajowym ${ }^{43}$. Podkreśla się również w literaturze, że TSUE dość liberalnie stosuje te warunki ${ }^{44}$, co zresztą tworzy dość dezorientujący obraz - są znane przypadki orzeczeń, w których za wywołujące bezpośrednie skutki uznawano przepisy niemające w ogóle mocy wiążącej, nieodnoszące się do żadnych uprawnień albo niezbyt precyzyjne ${ }^{45}$. Można twierdzić, że w pewnych wypadkach dla TSUE

37 Ibidem, s. 113.

${ }^{38}$ Ibidem, s. 125-127.

39 Ibidem, s. 132-133.

${ }^{40}$ Wyrok TSUE z dnia 30 kwietnia 1996 r. w sprawie C-194/94 CIA Security, pkt. 42-55.

${ }^{41}$ P. BRzeziŃski: Unijny obowiq̨zek..., s. 161; również cytowane wcześniej orzeczenia w sprawach van Gend en Loss oraz Becker; z nowszych orzeczeń - wyrok TSUE z dnia 7 lipca 2016 r. w sprawie C-46/15 Ambisig Ambiente e Sistemas de Informação Geográfica SA.

${ }^{42}$ Wyrok TSUE z dnia 4 grudnia 1974 r. w sprawie 41/74 Yvonne van Duyn.

${ }^{43}$ P. BRZEZIŃsKI: Unijny obowiazzek..., s. 161-162

44 A. Łazowski. W: Prawo instytucjonalne..., s. 307-308.

${ }^{45}$ K. LenaerTs, T. Corhaut: Towards an Internally Consistent Doctrine of Invoking Norms of EU Law. In: The Coherence of EU Law. The Search for Unity in Divergent Concepts. Ed. S. Prechal, B. van Roermund. Oxford 2008, p. 496 i cytowane tam przykłady orzeczeń. 
istotniejsze jest osiągnięcie celu określonej regulacji unijnej niż dokładnie wypełnianie, orzeczniczo przecież ustalonych, przesłanek bezpośredniej skuteczności na poziomie językowej redakcji przepisu.

$\mathrm{W}$ razie spełnienia omawianych warunków, przy braku implementacji dyrektywy do krajowego porządku prawnego, powstaje problem formy, jaką bezpośredni skutek dyrektywy ma w prawie krajowym przyjąć. Wszystko zależy od tego, czy dana materia jest w prawie krajowym uregulowana, a jeżeli tak, to w jakim zakresie i w jaki sposób. Ograniczmy się tu (ze względu na przedmiot rozważań) do sytuacji, gdy regulacja taka jest obecna $\mathrm{w}$ prawie krajowym. Jeżeli nie jest ona niezgodna $\mathrm{z}$ dyrektywą, a jedynie zbyt wąska w stosunku do przepisów dyrektywy, nie ulega wątpliwości, że normy wynikające z dyrektywy uzupełniają normy regulacji krajowej. Z kolei w wypadku sprzeczności z prawem krajowym dyrektywa wymaga odmowy zastosowania regulacji sprzecznej i albo znalezienia innych podstaw rozstrzygnięcia w prawie krajowym, albo oparcia się wprost na przepisach dyrektywy ${ }^{46}$. Możliwości te noszą odpowiednio nazwy doktryny wykluczenia i doktryny substytucji ${ }^{47}$, bowiem w pierwszym wypadku dochodzi do wykluczenia stosowania przepisu krajowego sprzecznego z dyrektywą (co samo w sobie, ściśle rzecz biorąc, jest przejawem zasady pierwszeństwa), zaś w drugim do zastosowania „w miejsce” normy krajowej - normy unijnej. Jeżeli natomiast żadne z tych rozwiązań nie jest dostępne (nie istnieje norma krajowa, która mogłaby zostać zastosowana, albo norma unijna nie spełnia warunków bezpośredniej stosowalności), obowiązkiem krajowego organu stosującego prawo (przede wszystkim - sądu krajowego) jest dokonanie prounijnej wykładni podlegających zastosowaniu przepisów prawa krajowego ${ }^{48} \mathrm{w}$ taki sposób, aby regulacja unijna została jak najpełniej urzeczywistniona $w$ krajowym porządku prawnym. Granicami wykładni prounijnej są jednak ogólne zasady prawa, w tym zakaz wykładni contra legem, czyli nadawania przepisowi krajowemu znaczenia całkowicie odmiennego od jego językowej treści taki rezultat prounijnej wykładni jest niedopuszczalny ${ }^{49}$. Podsumowując te uwagi, należy zgodzić się z N. Półtorak, że unijny standard ochrony prawnej posiada proceduralne pierwszeństwo i jest nadrzędny wobec standardu krajowego, stąd może stać się wzorcem dla oceny standardu

46 P. BRzezIŃski: Unijny obowiazzek..., s. 262-265.

${ }^{47}$ N. PóŁToraK: Ochrona uprawnień wynikających z prawa Unii Europejskiej w postępowaniach krajowych. Warszawa 2010, s. 183-184.

${ }^{48}$ Ibidem, s. 97-98.

49 Wyrok TSUE z dnia 16 czerwca 2005 r. w sprawie C-105/03 Maria Pupino, pkt 47; wyrok TSUE z dnia 4 lipca 2006 r. w sprawie C-212/04 Konstantinos Adeneler i inni, pkt 110; wyrok TSUE z dnia 24 stycznia 2012 r. w sprawie C-282/10 Maribel Dominguez, pkt 25. 
krajowego w procesie stosowania prawa lub upoważnić organ stosujący prawo do zastosowania rozwiązania zgodnego ze standardem unijnym, a w prawie krajowym nieprzewidzianego ${ }^{50}$.

\section{Polski standard dostępu do obrońcy w postępowaniu karnym wobec braku implementacji dyrektywy obrończej}

W świetle przedstawionych $\mathrm{w}$ punkcie 2 uwag, obrazujących rozbieżności między postanowieniami dyrektywy 2013/48/UE i przepisami k.p.k., oraz przedstawionych w punkcie 3 warunków przyznania dyrektywie skutku bezpośredniego $\mathrm{w}$ razie braku jej implementacji należy rozważyć, czy przepisy przedmiotowej dyrektywy mogą (a jeśli tak, to w jakim zakresie) być podstawą do powoływania się przez jednostki na określone uprawnienia związane $\mathrm{z}$ prawem do obrony formalnej $\mathrm{w}$ toku postępowania karnego. Zagadnieniem wstępnym jest stwierdzenie, czy dyrektywa obrończa może wywołać bezpośredni skutek, modyfikując zakres podmiotowy prawa do obrony formalnej - jak wyżej wskazano, istnieją pewne wątpliwości co do tego, komu to prawo przysługuje. Dyrektywa 2013/48/UE przewiduje, że stosuje się ją do „podejrzanych lub oskarżonych w postępowaniu karnym od chwili poinformowania ich przez właściwe organy państwa członkowskiego, za pomocą oficjalnego powiadomienia lub w inny sposób, o tym, że są podejrzani lub oskarżeni o popełnienie przestępstwa, niezależnie od tego, czy zostali pozbawieni wolności”. Zawartych w tym przepisie pojęć „podejrzany” i „oskarżony” nie można jednak tłumaczyć przez pryzmat ich znaczenia w prawie krajowym, bowiem naruszałoby to zasadę autonomii pojęć prawa unijnego. W wyroku w sprawie Deckmyn TSUE wyraźnie stwierdza, z powołaniem na swoje wcześniejsze orzecznictwo, że „treści przepisu prawa Unii, który nie zawiera wyraźnego odesłania do prawa państw członkowskich, dla określenia jego znaczenia i zakresu należy zwykle nadać w całej Unii autonomiczną i jednolitą wykładnię, którą należy ustalić, uwzględniając kontekst przepisu i cel danego uregulowania" ${ }^{51}$. Również porównanie tych terminów z innymi wersjami językowymi przedmiotowej dyrektywy przekonuje, że ta metoda wyjaśniania tych pojęć byłaby błędna. W wersji francuskiej użyto odpowiednio pojęć suspect i personne poursuivie; tymczasem we francuskiej procedurze karnej na oznaczenie strony biernej procesu w fazie przygotowawczej używa się, w zależności od formy tego

50 N. PóŁtorak: Ochrona uprawnień..., s. 94.

${ }^{51}$ Wyrok TSUE z dnia 3 września 2014 r. w sprawie C-201/13, Johan Deckmyn oraz Vrijheidsfonds VZW, pkt 14. 
postępowania, aż trzech terminów (personne soupçonnée, personne placée en garde à vue, personne mise en examen $)^{52}$; suspect odnosi się ogólnie, wręcz potocznie, do osoby podejrzanej o określone zachowanie (niekoniecznie zresztą w kontekście prawnym). Podobną sytuację mamy w wersji angielskiej - pojawiają się tam terminy suspect oraz accused person, podczas gdy w procesie karnym angielskim suspect nie posiada definicji legalnej: to po prostu osoba faktycznie podejrzana o popełnienie czynu i niebędąca stroną, albowiem angielska procedura karna nie zna sformalizowanej fazy przygotowawczej procesu karnego. Ukonstytuowanie się stron w tamtejszym procesie następuje dopiero po wniesieniu oskarżenia przed odpowiedni sąd (które jest de iure początkiem postępowania w sensie prawnym $)^{53}$. Z tych powodów kluczowe dla wyjaśnienia zakresu podmiotowego prawa do obrony formalnej na gruncie dyrektywy 2013/48/UE musi być zawarte $\mathrm{w}$ niej określenie terminu, od którego to prawo przysługuje, a zatem chwila poinformowania osoby przez właściwy organ państwa członkowskiego (oficjalnie lub w inny sposób) o byciu ściganym pod określonym zarzutem. Na gruncie k.p.k. oznacza to, że każda osoba podejrzana, niezależnie nawet od faktu zatrzymania, z którą dokonuje się czynności mających potwierdzić te podejrzenia ${ }^{54}$ lub wzywa do udziału w czynności przesłuchania w charakterze podejrzanego, jest podmiotem praw określonych w przedmiotowej dyrektywie i może korzystać z pomocy adwokata lub radcy prawnego, niezależnie od tego, czy można nazwać go na tym etapie obrońcą, czy też nie.

Po tych wstępnych ustaleniach wymaga przeanalizowania bezpośrednia skuteczność dyrektywy obrończej w kontekście wynikających z niej uprawnień - to one są bowiem esencją ustanowionego w dyrektywie standardu, a rozstrzygnięcie co do zakresu podmiotowego byłoby pozbawione znaczenia, gdyby przepisy dotyczące tych uprawnień nie mogły wywoływać skutku bezpośredniego. Co do pierwszego z nich, czyli prawa do spotkania się i porozumienia $\mathrm{z}$ adwokatem, polski porządek prawny co do zasady odzwierciedla normy ustanowione w przedmiotowej dyrektywie. Mówiąc potocznie, „diabeł tkwi w szczegółach”, albowiem istnieje szereg praktycznych problemów związanych z nawiązaniem kontaktu z obrońcą, choćby przez osobę zatrzymaną czy pozbawioną wolności, szczególnie gdy nie zna ona żadnego adwokata albo zachodzi konieczność przyznania jej pomocy prawnej z urzędu, a biegną terminy na wydanie przez sąd rozstrzygnięcia o jej tymczasowym aresztowaniu, co utrudnia szybkie ustanowienie i dopuszczenie obrońcy do czynności. Podzielić należy zgłaszane

52 J. GŁĘвосKA. W: System Prawa Karnego Procesowego. T. II: Proces karny - rozwiąania modelowe w ujęciu prawnoporównawczym. Red. P. KruszyŃski. Warszawa 2014, s. 268.

${ }^{53}$ K. Girdwoyń. W: System Prawa..., s. 751, 757.

54 A. Klamczyńska, T. Ostropolski: Prawo do adwokata..., s. 155. 
przez S. Steinborna propozycje usprawnienia tych pozornie technicznych, a przemożnie oddziałujących na prawo do obrony, unormowań ${ }^{55}$, stwierdzając zarazem, że kwestie te wymagają interwencji ustawodawczej, gdyż trudno byłoby wywodzić z dyrektywy obrończej aż tak szczegółowe skutki, dotyczące choćby tymczasowego przyznawania obrońcy z urzędu i metody rozliczania kosztu procesu $\mathrm{w}$ ten sposób wygenerowanego. Odpowiednia organizacja organów wymiaru sprawiedliwości i ich ścisła współpraca w tym zakresie z korporacją adwokacką i radcowską mogłaby ponadto, bez zmian na poziomie ustawy, samoistnie usprawnić szereg elementów utrudniających szybkie ustanowienie obrońcy.

Drugie z uprawnień, czyli prawo do obecności i bezpośredniego udziału adwokata w przesłuchaniu osoby ściganej, jest w dyrektywie 2013/48/UE zarysowane szerzej niż w treści art. 301 k.p.k. Należy przede wszystkim zwrócić uwagę, że odpowiednie postanowienia przedmiotowej dyrektywy nie są adresowane wyłącznie do państw członkowskich, ale również bezpośrednio do jednostek. Kluczowy przepis art. 3 dyrektywy obrończej, o ile w ust. 1 kieruje się do państw członkowskich, mających zapewnić podejrzanym lub oskarżonym prawo do adwokata, o tyle już w ust. 2 stanowi, że podmioty te mają prawo dostępu do adwokata bez zbędnej zwłoki, precyzyjnie zarazem ustalając terminy, w których prawo to w indywidualnej sytuacji powstaje. Przepis ten wyraźnie wskazuje beneficjenta uprawnienia i dokładnie określa jego zakres temporalny, przez co spełnia warunki jasności, precyzji i bezwarunkowości i może być bezpośrednio stosowany - spełnia przesłanki skutku bezpośredniego w znaczeniu subiektywnym, w ramach którego łatwiej jest ten bezpośredni skutek konstruować. Podobnie jest z ust. 3 omawianego artykułu, który precyzuje uprawnienia składające się na prawo do adwokata, a jednym $\mathrm{z}$ nich jest omawiane tu prawo do udziału w przesłuchaniu. Przedmiotowa dyrektywa zastrzega, co prawda, że „,[t]aki udział musi być zgodny z procedurami określonymi w prawie krajowym, pod warunkiem, że takie procedury pozostają bez uszczerbku dla skutecznego wykonywania odnośnego prawa i dla jego istoty", lecz nie można traktować tego zastrzeżenia jako czyniącego analizowany przepis warunkowym, zależnym od sposobu transpozycji przedmiotowej dyrektywy w państwie członkowskim. Stwierdzenie, że udział ten musi być zgodny z procedurami danego państwa członkowskiego, jest wyłącznie wyrazem poszanowania autonomii proceduralnej państw członkowskich ${ }^{56}$; jednocześnie to ochrona tej autonomii, a nie

55 S. STEInborn: Dostęp do obrońcy..., s. 39-41.

56 Przez autonomię proceduralną rozumie się „kompetencję państw członkowskich do uregulowania właściwości sądów i procedur do rozpoznawania spraw opartych na prawie wspólnotowym" - A. WRóBel: Autonomia proceduralna państw członkowskich. Zasada efektywności i zasada efektywnej ochrony sqdowej w prawie Unii Europejskiej. RPEiS 2005, z. 1, s. 35. 
zastosowanie przepisu dyrektywy, jest uwarunkowane zgodnością procedury krajowej z istotą prawa dostępu do adwokata oraz skutecznością jego wykonywania. Można powiedzieć, że przepis ten wyraźnie oddziela istotę omawianego uprawnienia od szczegółowych, często technicznych, okoliczności jego wykonywania. Wynika z tego, że bezpośrednio w oparciu o przepisy przedmiotowej dyrektywy jednostka może żądać przesłuchania z udziałem obrońcy, a zawarte w prawie krajowym ograniczenia nie powinny mieć zastosowania. Ponadto trzeba zauważyć, że ograniczenia przewidziane $\mathrm{w}$ polskim procesie karnym są związane nie tyle z językową treścią art. 301 k.p.k., ale z jego określoną, wyżej omawianą, interpretacją. Przepis ten nie zakazuje przecież odroczenia przesłuchania w celu ustanowienia obrońcy, nie formułuje też nakazu przesłuchania pomimo niestawiennictwa obrońcy ani nie limituje tego prawa do pierwszego przesłuchania, co czyniłoby je uprawnieniem jednorazowym. Trudno tu nawet mówić o wyraźnej sprzeczności art. 301 k.p.k. z dyrektywą obrończą - przedmiotowy akt prawa UE raczej uzupełnia, niż zastępuje tę regulację normatywną, wywołując swój bezpośredni skutek.

W wypadku trzeciego z uprawnień, czyli udziału obrońcy w czynnościach dowodowych niepowtarzalnych, sytuacja jest zdecydowanie bardziej złożona. Odpowiednie postanowienia przedmiotowej dyrektywy wskazują jedynie trzy czynności objęte minimalnym standardem, uzależniając ponadto jego zastosowanie od obecności tych czynności w krajowym prawie dowodowym oraz wymogu bądź zezwolenia na obecność podejrzanego lub oskarżonego w toku tych czynności. Próba konstruowania skutku bezpośredniego w odniesieniu do czynności niepowtarzalnych niewymienionych w art. 3 ust. 3 lit. c przedmiotowej dyrektywy jest z góry wykluczona, bowiem przepis dyrektywy ich po prostu nie obejmuje. W odniesieniu do czynności wymienionych w tym przepisie należałoby wyjaśnić, o jakie czynności chodzi. „Okazanie w celu rozpoznania” może oznaczać w prawie polskim okazanie osoby lub rzeczy. Wersja francuska dyrektywy jest bardziej precyzyjna - użyto tam wyrażenia séances d'identification des suspects, co oznacza okazanie osób podejrzanych w celu rozpoznania innym osobom. Udział jednostki będącej podmiotem praw określonych w dyrektywie obrończej w tej czynności jest w takim razie per se oczywisty. Podobnie jest z czynnością „eksperymentów procesowych polegających na odtworzeniu przebiegu przestępstwa" - porównanie $z$ wersjami językowymi francuską i angielską przedmiotowej dyrektywy także przekonuje, że chodzi tu o tzw. wizję lokalną z udziałem oskarżonego, stąd jego obecność jest tam naturalnie wymagana. Najbardziej problematyczna jest czynność „konfrontacji”, bowiem dyrektywa obrończa nie precyzuje, czy chodzi tu o konfrontację oskarżonego 
z innymi osobowymi źródłami dowodowymi (wówczas jego obecność jest konieczna) czy też przykładowo o konfrontację dwóch świadków, których zeznania mogą mieć znaczenie dla odpowiedzialności oskarżonego (wtedy oskarżony może brać w tej czynności co do zasady udział, z zastrzeżeniem specyficznej regulacji jego lub obrońcy obecności w toku tej czynności w postępowaniu przygotowawczym, zgodnie $\mathrm{z}$ treścią art. 315-317 k.p.k.). Omawiany przepis przedmiotowej dyrektywy nie wymaga doprecyzowania w prawie krajowym wyłącznie $\mathrm{w}$ odniesieniu do czynności okazania podejrzanego lub oskarżonego oraz czynności eksperymentu procesowego połączonego z oględzinami miejsca zdarzenia. Zwrócić należy zarazem uwagę, że zakres kompetencji obrońcy w toku tych czynności ograniczony jest w treści dyrektywy w porównaniu do kompetencji w toku czynności przesłuchania podejrzanego: obrońca ma tylko prawo do obecności, nie ma natomiast zagwarantowanego dyrektywą prawa do „skutecznego udziału”; nie przewidziano również protokolarnego odnotowania jego obecności. Wydaje się, że w zakresie opisywanego uprawnienia postanowienia dyrektywy obrończej uzależniają je zbyt silnie od norm prawa krajowego, przez co przepis art. 3 ust. 3 lit. c zdecydowanie trudniej uznać za samowykonalny - chyba że przyjąć, iż chodzi tu o skutek bezpośredni w znaczeniu obiektywnym. Gdyby teza o wywoływaniu przez ten przepis skutku bezpośredniego została uznana za zbyt daleko idącą, należałoby jednak rozważyć dokonywanie prounijnej wykładni odpowiednich przepisów k.p.k. (choćby art. 117 k.p.k. oraz art. 315-317 k.p.k.) w ten sposób, aby na ich gruncie zapewnienie obecności obrońcy w czynnościach opisanych w przedmiotowej dyrektywie uznać za niezbędne.

Odnosząc się do ograniczeń praw przewidzianych w dyrektywie obrończej, opisanych w art. 3 ust. 6 przedmiotowej dyrektywy, wskazać jedynie należy, że bez względu na treść prawa krajowego wymagają one bezpośredniej transpozycji. Stanowią bowiem klauzule ograniczające uprawnienia jednostek względem państwa, a tego rodzaju postanowienia dyrektyw nie wywołują skutku bezpośredniego ${ }^{57}$. Aby powołać się na te wyjątki, treść prawa krajowego musi je wprost inkorporować (co w wypadku k.p.k. w szczególny sposób dotyczy wyjątku z litery a) w art. 3 ust. 6 dyrektywy 2013/48/UE).

Powyższą argumentację językową, zgodnie z którą określone w dyrektywie obrończej uprawnienia do kontaktu z obrońcą oraz do jego aktywnego udziału w przesłuchaniu podejrzanego lub oskarżonego wywołują skutek bezpośredni w prawie krajowym, należy uzupełnić o kilka argumentów natury systematycznej i celowościowej. Przepisy przedmiotowej

57 Wyrok w sprawie Ratti (vide przyp. 33), passim. 
dyrektywy odnoszące się do wzmiankowanych uprawnień, składających się na prawo do obrony formalnej, w wyraźny sposób odróżniają się od jej pozostałych postanowień, bowiem explicite stanowią, że to „podejrzani lub oskarżeni mają prawo do [...]". Szereg kolejnych artykułów dyrektywy 2013/48/UE, mimo że w tytule zawiera wyrażenie „prawo do [...]” (np. art. 6: „Prawo do porozumiewania się z osobami trzecimi w czasie pozbawienia wolności”), stosuje konwencję językową adresującą te przepisy do państw: ,państwa członkowskie zapewniają, aby podejrzani lub oskarżeni [...]". Widać tu wyraźną próbę podkreślenia samodzielności uprawnień wynikających z art. 3 przedmiotowej dyrektywy, co ma niebagatelne znaczenie w kontekście subiektywnego znaczenia skutku bezpośredniego. Nie można tracić również z pola widzenia faktu, że dyrektywa obrończa posiada stosunkowo długą preambułę (59 motywów), a tekst regulacyjny jest dość zwięzły. W literaturze zwrócono uwagę, że bywa to oznaką braku porozumienia między podmiotami procesu prawodawczego co do niektórych norm wyraźnie zobowiązujących do konkretnych działań (czego dowodzą wspomniane w punkcie 1 niniejszego opracowania trudności negocjacyjne oraz ich rezultat w odniesieniu do art. 12 ust. 2 dyrektywy), jak i zarazem większej precyzji tekstu regulacyjnego, zawierającego ściśle określone standardy ${ }^{58}$. Preambuła dyrektywy obrończej zawiera wiele istotnych z praktycznego punktu widzenia stwierdzeń, których jednak nie inkorporowano do tekstu regulacyjnego - przykładowo motyw 31 in fine przewiduje, w odniesieniu do odstępstw czasowych od prawa dostępu do adwokata ze względu na zagrożenie dla życia lub zdrowia osób, że przesłuchanie podejrzanego lub oskarżonego w takich okolicznościach „może być prowadzone wyłącznie w celu i w stopniu koniecznym do uzyskania informacji niezbędnych dla zapobieżenia poważnym negatywnym konsekwencjom dla życia, wolności lub nietykalności cielesnej jakiejś osoby. Jakiekolwiek nadużycie takiego odstępstwa co do zasady nieodwracalnie naruszyłoby prawo do obrony" 59 . Wynika z tego jasno, że przesłuchanie bez obrońcy powinno być prowadzone tylko do momentu uzyskania informacji pozwalających zapobiec tym negatywnym skutkom, a w dalszym ciągu obecność obrońcy powinna być zapewniona (chodzi o uniknięcie sytuacji, w których wyjątek służyłby do obchodzenia prawa dostępu do adwokata). Niemniej tekst regulacyjny nie zawiera odpowiednika cytowanego stwierdzenia. Nakazuje to sądzić, że uprawnienia przewidziane w niektórych przynamniej numerowanych (i wyżej omówionych) artykułach przedmiotowej dyrektywy są maksymalnie precyzyjne, a intencją

58 V. Mitsilegas: EU Criminal Law After Lisbon. Rights, Trust and the Transformation of Justice in Europe. Oxford-Portland-Oregon 2016, p. 166.

${ }_{59}$ Chodzi tu zapewne o tzw. safety interviews - por. M. WĄsEK-WIADEREK: Dostęp do adwokata..., s. 21. 
ustawodawcy unijnego było nadanie im cech umożliwiających wywoływanie skutku bezpośredniego (który nie będzie jednak dotyczył, między innymi, niezmiernie istotnych stwierdzeń motywu 31).

Przypomnieć wreszcie należy, że prawo do obrony konkretyzowane przez przedmiotową dyrektywę, na co zwraca uwagę cytowany już motyw 6 jej preambuły, jest wyrażone w prawie pierwotnym UE, a mianowicie w art. 48 ust. 2 Karty Praw Podstawowych, zaś sama dyrektywa w zakresie uprawnienia do kontaktu $\mathrm{z}$ adwokatem $\mathrm{i}$ jego udziału w przesłuchaniu podejrzanego wprost wyraża wspomnianą już doktrynę Salduz ${ }^{60}$. Prawa podstawowe określone w Europejskiej Konwencji Praw Człowieka stanowią natomiast część acquis communautaire (art. 6 ust. 3 Traktatu o Unii Europejskiej). Intencją ustawodawcy unijnego było zatem uczynienie uprawnień do kontaktu z adwokatem i jego obecności podczas przesłuchania standardem minimalnym, bezwarunkowym i dostatecznie precyzyjnym, by mógł zaistnieć nawet $\mathrm{w}$ razie braku implementacji dyrektywy. Słusznie się bowiem zauważa, że dostęp do adwokata to kamień węgielny uprawnień procesowych w postępowaniu karnym, swoiste „prawobrama” (gateway right), umożliwiające wykonywanie innych uprawnień procesowych $^{61}$.

\section{Uwagi podsumowujące}

W konkluzji niniejszego opracowania należy raz jeszcze podkreślić, że wobec braku implementacji dyrektywy obrończej kwestia jej skutku bezpośredniego staje się coraz bardziej aktualnym wyzwaniem dla praktyki wymiaru sprawiedliwości. Czynności z udziałem podejrzanego lub oskarżonego, prowadzone $\mathrm{z}$ naruszeniem standardu określonego $\mathrm{w}$ dyrektywie 2013/48/UE, mogą być na tej podstawie kwestionowane przez obronę $\mathrm{w}$ toczących się i przyszłych postępowaniach karnych. Niemniej istnieją poważne argumenty przemawiające za tym, że przynajmniej niektóre przepisy przedmiotowej dyrektywy wywołują bezpośredni skutek. Dotyczy to przede wszystkim prawa do kontaktu z obrońcą oraz prawa do obecności i udziału obrońcy w przesłuchaniu osoby ściganej. Konsekwencją tych ustaleń jest uznanie, że podejrzany lub oskarżony ma prawo żądać kontaktu z obrońcą na każdym etapie postępowania, a także ma prawo domagać się jego obecności podczas przesłuchania - zarówno pierwszego, jak i każdego kolejnego w sprawie. Organ procesowy winien odroczyć czynność w razie usprawiedliwionego niestawiennictwa obrońcy albo w ra-

\footnotetext{
${ }^{60}$ V. Mitsilegas: EU Criminal Law..., p. 168.

${ }^{61}$ Ibidem, p. 165-166.
} 
zie potrzeby jego ustanowienia, a obrońca winien móc wypowiadać się w czasie czynności przesłuchania, w tym zadawać pytania swojemu mocodawcy i składać oświadczenia co do przebiegu tej czynności, co powinno być odnotowywane $\mathrm{w}$ jej protokole. Nie ulega wątpliwości, że bezwarunkowy charakter tych uprawnień może być dla praktyki polskich organów ścigania znaczącym wyzwaniem na poziomie trudności faktycznych, tj. posiadanych sił i środków. Nie usprawiedliwia to jednak nieprzestrzegania omawianych przepisów prawa unijnego, bowiem państwo nie może, o czym była mowa, tłumaczyć niekorzystnego dla jednostki postępowania jego organów własnymi zaniechaniami prawodawczymi czy administracyjnymi. Ten stan rzeczy jedynie dowodzi, że brak implementacji dyrektywy obrończej tylko pogarsza istniejącą sytuację, bowiem odpowiednie transponowanie przepisów przedmiotowej dyrektywy mogłoby zarówno dotrzymać kroku ustanowionym w niej standardom, jak i uwzględnić realia polskiego wymiaru sprawiedliwości. Konsekwencje nieimplementacji dyrektywy 2013/48/UE nie mogą jednak obciążać osób ściganych, przy czym trzeba przyznać, że z przedmiotowej dyrektywy nie wynikają wprost konsekwencje posługiwania się dowodami zgromadzonymi z naruszeniem prawa do adwokata (np. wyjaśnieniami podejrzanego złożonymi bez jego udziału albo protokołem okazania przeprowadzonego pod jego nieobecność). Jak już sygnalizowano, art. 12 ust. 2 dyrektywy obrończej statuuje nakaz ostrożnej, szczegółowej i krytycznej sądowej weryfikacji tak zgromadzonych dowodów, ale nie można tej normy traktować jako klauzuli automatycznie dyskwalifikującej taki materiał dowodowy. Rozwiązanie tej kwestii pozostawione jest prawu krajowe$\mathrm{mu}$, niemniej tu również wskazana jest prounijna wykładnia przepisów prawa dowodowego i próba podtrzymania reguł wynikających, za jego pośrednictwem, z art. 6 EKPC oraz doktryny Salduz. Brak jakichkolwiek sankcji z tytułu naruszenia gwarancji określonych w dyrektywie uczyni je iluzorycznymi i podważy efektywność transpozycji prawa unijnego do krajowego porządku prawnego ${ }^{62}$.

Niestety dalsze traktowanie w opisywany tu sposób dyrektyw unijnych odnoszących się do postępowania karnego będzie powodować narastanie podobnych do opisanych wyżej problemów - w ostatnich latach rośnie bowiem liczba dyrektyw dotyczących procesu karnego ${ }^{63}$. Do polskiego porządku prawnego transponowano dyrektywy dotyczące tłumaczeń w postępowaniu karnym i prawa do informacji w postępowaniu karnym, co nastąpiło na mocy ustawy z dnia 27 września 2013 r. o zmianie

${ }^{62}$ Podobnie S. Steinborn: Dostęp do obrońcy..., s. 45-56.

${ }^{63}$ Co do adresów publikacyjnych wymienianych w dalszym wywodzie dyrektyw vide przyp. 2. 
ustawy - Kodeks postępowania karnego oraz niektórych innych ustaw ${ }^{64}$. Transpozycji doczekały się również tzw. dyrektywa o prawach ofiar oraz dyrektywa odnosząca się do europejskiego nakazu ochrony (za pośrednictwem ustawy z dnia 28 listopada 2014 r. o ochronie i pomocy dla świadka i pokrzywdzonego ${ }^{65}$ ). Ostatnio wdrożona zaś została dyrektywa odnosząca się do europejskiego nakazu dochodzeniowego (wspomnianą już ustawą z dnia 10 stycznia 2018 r. o zmienia ustawy - Kodeks postępowania karnego oraz niektórych innych ustaw). Obecnie, poza dyrektywą obrończą, na realną transpozycję oczekuje tzw. dyrektywa „niewinnościowa”"66, której termin implementacji minął 1 kwietnia 2018 r. Ta ostatnia dyrektywa przewiduje $\mathrm{w}$ istocie rozciągnięcie reguły in dubio pro reo na wszystkie fazy postępowania karnego (co wynika $\mathrm{z}$ art. $2 \mathrm{w}$ zw. $\mathrm{z}$ art. 6 ust. 2 dyrektywy „niewinnościowej”). Dyrektywa ta zawiera również rozbudowane gwarancje obecności na rozprawie oskarżonego, albo co najmniej jego obrońcy, o czym stanowi art. 8 tejże dyrektywy. Zaskoczenie budzi w związku z tym treść nowelizacji k.p.k., która weszła w życie 5 października 2019 r. ${ }^{67}$, zdaje się ona bowiem powtarzać schemat działania taki, jak w sprawie implementacji dyrektywy obrończej. W tej ustawie dodano do tytułu k.p.k. odnośnik informujący o tym, że ustawa ta wykonuje postanowienia dyrektywy „niewinnościowej”, mimo że art. 5 k.p.k. ani żaden inny przepis odnoszący się choćby pośrednio do domniemania niewinności nie zostaje zmieniony. Co więcej, dodano do ustawy karnoprocesowej art. 378a k.p.k., zezwalający sądom na prowadzenie w szerokim zakresie postępowania dowodowego bez udziału oskarżonego lub obrońcy, nawet w razie usprawiedliwienia niestawiennictwa lub wystąpienia siły wyższej, co prima facie jest sprzeczne z przepisami dyrektywy „niewinnościowej”, a $\mathrm{w}$ pośredni sposób naruszać może standardy omawianej w niniejszym opracowaniu dyrektywy 2013/48/UE.

Jakkolwiek temat dyrektywy „niewinnościowej” domaga się odrębnego opracowania, to na jej przykładzie oraz na przykładzie dyrektywy obrończej widać niepokojącą $\mathrm{w}$ dłuższej perspektywie tendencję $\mathrm{w}$ postępowaniu polskiego ustawodawcy $\mathrm{w}$ ostatnim czasie. Implementacji doczekały się w zasadzie wyłącznie dyrektywy wzmacniające pozycję pokrzywdzonego i świadka „wrażliwego” w postępowaniu karnym oraz dy-

${ }^{64}$ Dz.U. poz. 1247.

${ }_{65}$ Dz.U. 2015, poz. 21.

${ }^{66}$ Dyrektywa Parlamentu Europejskiego i Rady (UE) 2016/1919 z dnia 26 października 2016 r. w sprawie pomocy prawnej z urzędu dla podejrzanych i oskarżonych w postępowaniu karnym oraz dla osób, których dotyczy wniosek w postępowaniu dotyczącym europejskiego nakazu aresztowania, Dz.Urz.UE L 297/1 z dnia 4 listopada 2016 r.

${ }^{67}$ Ustawa z dnia 19 lipca 2019 r. o zmianie ustawy - Kodeks postępowania karnego oraz niektórych innych ustaw, Dz.U. poz. 1694. 
rektywy usprawniające pracę organów ścigania w sprawach z elementem transgranicznym. Dyrektywy o charakterze gwarancyjnym dla oskarżonego są transponowane pozornie, nominalnie, bez realnego dostosowania treści k.p.k. do ich wymogów, a wręcz w sposób z nimi sprzeczny (co dotyczy, jak się wydaje, dyrektywy „niewinnościowej”). Nie dostrzega się, że dyrektywy unijne, choć normują różne aspekty postępowania karnego, stanowią spójny plan harmonizacji procedur karnych państw członkowskich, który może być efektywnie wdrażany tylko w całości, a nie fragmentarycznie. Działania UE w sferze wymiaru sprawiedliwości karnej są zresztą przejawem tendencji do zmniejszania się autonomii proceduralnej państw członkowskich ${ }^{68}$, albowiem uregulowanie kwestii proceduralnych w prawie unijnym wyklucza tę autonomię po stronie procedury krajowej ${ }^{69}$.

Można przewidywać, że skutkiem omawianych wyżej zaniedbań w zakresie transpozycji regulacji unijnych będzie zaburzenie aksjologicznej równowagi k.p.k., pogorszające pozycję oskarżonego. Obserwowana będzie również postępująca dysfunkcjonalność i niespójność jego przepisów, niezależnie nawet od narastającej dekompozycji jego struktury normatywnej (związanej szczególnie z uporczywym nowelizowaniem działu XIII k.p.k., podczas gdy wskazane byłoby uchwalenie odrębnej ustawy regulującej problematykę międzynarodową procesu karnego ${ }^{70}$ ). Niespełnianie omawianych wcześniej standardów przez polską procedurę karną osłabiać będzie zaufanie innych państw członkowskich w zakresie wzajemnego uznawania i wykonalności orzeczeń, do czego jedynie preludium są powstające w ostatnich kilkunastu miesiącach kontrowersje wokół dopuszczalności wykonywania przez inne państwa członkowskie europejskich nakazów aresztowania wystawianych przez sądy polskie ${ }^{71}$. Można zaryzykować tezę, że niewdrożenie dyrektywy obrończej pogłębi w innych państwach członkowskich wątpliwości co do rzetelności polskiego procesu karnego, bowiem ignorowanie unijnych standardów gwarancyjnych może mieć $\mathrm{w}$ praktyce większe przełożenie na ocenę tej rzetelności niż tzw. kryzys praworządności, rozgrywający się na poziomie niezawisłości i organizacji całego sądownictwa. Materia dyrektywy 2013/48/UE jest bowiem ze swojej natury bliższa problemom konkretnych spraw, w których taka ocena może być potencjalnie dokonywana,

68 A. WRóbel: Autonomia proceduralna..., s. 39.

${ }^{69}$ Ibidem, s. 37.

${ }^{70} \mathrm{Na}$ potrzebę ujęcia tej, często nowelizowanej, materii normatywnej w odrębnej ustawie słusznie zwracają uwagę P. Hofmański, S. Waltoś: Proces karny. Zarys systemu. Warszawa 2016, s. 620.

${ }^{71}$ Wyrok TSUE z dnia 25 lipca 2018 r. w sprawie C-216/18 PPU L.M. (tzw. sprawa Celmera). 
niż systemowe zagrożenia dla niezawisłości sędziowskiej i niezależności władzy sądowniczej. Problematyka implementacji tej (i innych) dyrektyw nie ogranicza się zresztą tylko do materii ściśle karnoprocesowej - brak wspólnych rozwiązań gwarancyjnych w różnych krajach UE hamuje korzystanie przez jednostki ze swobodnego przepływu osób, z powodu lęku przed niższym standardem proceduralnym $\mathrm{w}$ innym państwie ${ }^{72}$. Nie można nie wyrazić obawy, że taki stan rzeczy będzie oddziaływał również na inne swobody wspólnego rynku.

W świetle powyższego postulować należy niezwłoczną i realną transpozycję dyrektywy obrończej, albowiem proponowana $\mathrm{w}$ tym opracowaniu bezpośrednia skuteczność tego aktu nie może być rozwiązaniem trwale stosowanym, a powinna być jedynie środkiem prowizorycznym, do którego uciekać się będą organy procesowe w oczekiwaniu na prawidłową implementację dyrektywy 2013/48/UE.

\section{Bibliografia}

\section{Literatura}

BRZEZIŃsKI P.: Unijny obowiazek odmowy zastosowania przez sąd krajowy ustawy niezgodnej z dyrektywa Unii Europejskiej. Warszawa 2010.

Girdwoyń K., Komar-Nalepa A.: Dziat VI. Angielski proces karny. W: System Prawa Karnego Procesowego. T. II: Proces karny - rozwiazania modelowe w ujęciu prawnoporównawczym. Red. P. KRUszYŃsKI. Warszawa 2014.

GŁęвоска J.: Dziat II. Francuska procedura karna. W: System Prawa Karnego Procesowego. T. II: Proces karny - rozwiqzania modelowe $w$ ujęciu prawnoporównawczym. Red. P. KRuszyŃsKI. Warszawa 2014.

GóralczyK W., SaWicki S.: Prawo międzynarodowe publiczne w zarysie. Warszawa 2011.

Hofmański P., WaLtoś S.: Proces karny. Zarys systemu. Warszawa 2016.

KlamcZyŃsKa A., Ostropolski T.: Prawo do adwokata $w$ dyrektywie 2013/48/UE tto europejskie i implikacje dla polskiego ustawodawcy. „Białostockie Studia Prawnicze" 2014, z. 15.

Koncewicz T., Podolska A.: Dostęp do adwokata $w$ postępowaniu karnym. Pal. 2017, $\mathrm{nr} 9$.

KOPER R.: Prawo do obrony osoby podejrzanej. PiP 2016, nr 2.

LENAERTS K., CORHAUT T.: Towards an Internally Consistent Doctrine of Invoking Norms of EU Law. In: The Coherence of EU Law. The Search for Unity in Divergent Concepts. Ed. S. PReChaL, B. van RoERMUND. Oxford 2008.

MitsiLegas V.: EU Criminal Law After Lisbon. Rights, Trust and the Transformation of Justice in Europe. Oxford-Portland-Oregon 2016.

72 M. RogacKa-RzewnicKa: Wptyw prawodawstwa..., s. 250-251. 
PóŁToraK N.: Ochrona uprawnień wynikajacych z prawa Unii Europejskiej w postępowaniach krajowych. Warszawa 2010.

Prawo instytucjonalne Unii Europejskiej. Red. M.M. Kenig-WitKowsKa. Warszawa 2015.

RogacKa-RzewnicKa M.: Wptyw prawodawstwa unijnego na pozycje procesowa oskarżonego. W: Prawne problemy $i$ wyzwania Unii Europejskiej. Red. Ł. PisArczyK. Warszawa 2018.

STEINBORn S.: Dostęp do obrońcy na wczesnym etapie postępowania karnego. Uwagi de lege lata $i$ de lege ferenda. EPS 2019, nr 1.

WąSEK-WIADEREK M.: Dostęp do adwokata na wczesnym etapie postępowania karnego w prawie Unii Europejskiej. EPS 2019, nr 1.

WróBel A.: Autonomia proceduralna państw członkowskich. Zasada efektywności $i$ zasada efektywnej ochrony sadowej w prawie Unii Europejskiej. RPEiS 2005, z. 1 .

\section{Orzecznictwo}

Wyrok TSUE z dnia 5 lutego 1963 r. w sprawie 26/62 NV Algemene Transport en Expeditie Onderneming van Gend \& Loos.

Wyrok TSUE z dnia 4 grudnia 1974 r. w sprawie 41/74 Yvonne van Duyn.

Wyrok TSUE z dnia 5 kwietnia 1979 r. w sprawie 148/78 Tullio Ratti.

Wyrok TSUE z dnia 19 stycznia 1982 r. w sprawie 8/81 Ursula Becker.

Wyrok TSUE z dnia 30 kwietnia 1996 r. w sprawie C-194/94 CIA Security.

Wyrok TSUE z dnia 5 października 2004 r. w sprawach połączonych od C-397/01 do C-403/01 Bernhard Pfeiffer i inni.

Wyrok TSUE z dnia 16 czerwca 2005 r. w sprawie C-105/03 Maria Pupino.

Wyrok TSUE z dnia 4 lipca 2006 r. w sprawie C-212/04 Konstantinos Adeneler i inni.

Wyrok TSUE z dnia 24 stycznia 2012 r. w sprawie C-282/10 Maribel Dominguez.

Wyrok TSUE z dnia 3 września 2014 r. w sprawie C-201/13 Johan Deckmyn oraz Vrijheidsfonds VZW.

Wyrok TSUE z dnia 7 lipca 2016 r. w sprawie C-46/15 Ambisig Ambiente e Sistemas de Informação Geográfica SA.

Wyrok TK z dnia 11 grudnia 2012 roku, K 37/11, OTK ZU 11A/2012, poz. 133.

\section{Źródła internetowe}

Opinia Komisji Kodyfikacyjnej Prawa Karnego $w$ sprawie implementacji $w$ prawie polskim dyrektywy Parlamentu Europejskiego i Rady 2013/48/UE z dnia 22 października 2013 r. w sprawie prawa dostępu do adwokata $w$ postępowaniu karnym i $w$ postępowaniu dotyczacym europejskiego nakazu aresztowania oraz $w$ sprawie prawa do poinformowania osoby trzeciej o pozbawieniu wolności $i$ prawa do porozumiewania się z osobami trzecimi i organami konsularnymi w czasie pozbawienia wolności. Oprac. S. STEINBORN. Źródło: https://bip.ms.gov. $\mathrm{pl} / \mathrm{pl} /$ dzialalnosc/komisje-kodyfikacyjne/komisja-kodyfikacyjna-prawa-kar nego/opinie-komisji-kodyfikacyjnej-prawa-karnego/ [dostęp: 7.03.2020]. 